\title{
Treatment options for patients with triple-negative breast cancer
}

\author{
Rafael Santana-Davila ${ }^{1}$, Edith A Perez ${ }^{2^{*}}$
}

\begin{abstract}
Breast cancer is a heterogeneous disease composed of different subtypes, characterized by their different clinicopathological characteristics, prognoses and responses to treatment. In the past decade, significant advances have been made in the treatment of breast cancer sensitive to hormonal treatments, as well as in patients whose malignant cells overexpress or amplify HER2. In contrast, mainly due to the lack of molecular targets, little progress has been made in the treatment of patients with triple-negative breast cancer. Recent improved understanding of the natural history, pathophysiology, and molecular features of triple-negative breast cancers have provided new insights into management and therapeutic strategies for women affected with this entity. Ongoing and planned translational clinical trials are likely to optimize and improve treatment of women with this disease.
\end{abstract}

\section{Introduction}

Breast cancer affected an estimated 192,370 women and men in 2009, and was responsible for 40,170 deaths during the same year [1]. It is now clear that it is a disease composed of multiple subgroups characterized by their pathophysiological features, outcomes, and responses to treatment. The heterogeneity of this disease underscores the need for treatments to be tailored for a specific patient, depending on the molecular characteristics of their malignancy.

An initial subdivision of patients with breast cancer can be done by immunohistochemical techniques separating those whose malignant cells express either estrogen (ER) or progesterone receptors (PgR) and those that do not, as the first two can be treated with endocrine therapy. Immunohistochemistry (IHC) or fluorescence in situ hybridization (FISH) can also detect the overexpression (or amplification) of the human epidermal growth factor receptor 2 (HER2), which can also be targeted therapeutically with antibodies or small molecule tyrosine kinase inhibitors. Tumors that do not express ER, PgR, or HER2 are commonly referred to as triplenegative breast cancer (TNBC).

Further understanding of the biology of breast cancer comes from studies that have identified gene expression

\footnotetext{
* Correspondence: perez.edith@mayo.edu

2Division of Hematology and Oncology Mayo Clinic, 4500 San Pablo Road, Jacksonville, Florida. 32224. USA

Full list of author information is available at the end of the article
}

profiles that provide insight into therapeutic strategies, although more work remains to be done [2-6]. Perou and colleagues $[4,5]$ proposed an initial classification in which breast cancer was subdivided into four groups: Luminal types A and B, HER2 positive cancer and basal-like subset. Luminal type A is characterized by neoplasms that express ER and have a low-grade histology. Luminal type B is composed mostly of tumors with low ER expression and a higher grade compared to those with type A. HER2 positive cancers are distinguished by the amplification of the HER2 gene. Finally, the basal-like subset, which is composed mostly of ER and HER2 negative cancers. This is, of course, an oversimplification of the heterogeneity of breast cancer, albeit helpful based on the current status of knowledge.

\section{TNBC and Basal-like Cancer}

Although the terms TNBC and basal-like cancer are often used interchangeably, it is important to clarify that not all TNBCs belong to the basal-like subtype (Figure 1). Although one of the key features of most basal-like cancers is the low expression of hormonal receptors and HER2 related genes, they are also characterized by other features. This was illustrated in the study by Parker and collaborators who, in an attempt to incorporate gene expression based "intrinsic" molecular subtypes for prognosis and prediction of chemotherapy benefit, applied a 50 gene expression signature (PAM50) to a cohort of 1,004 patients, of which 626 had ER 


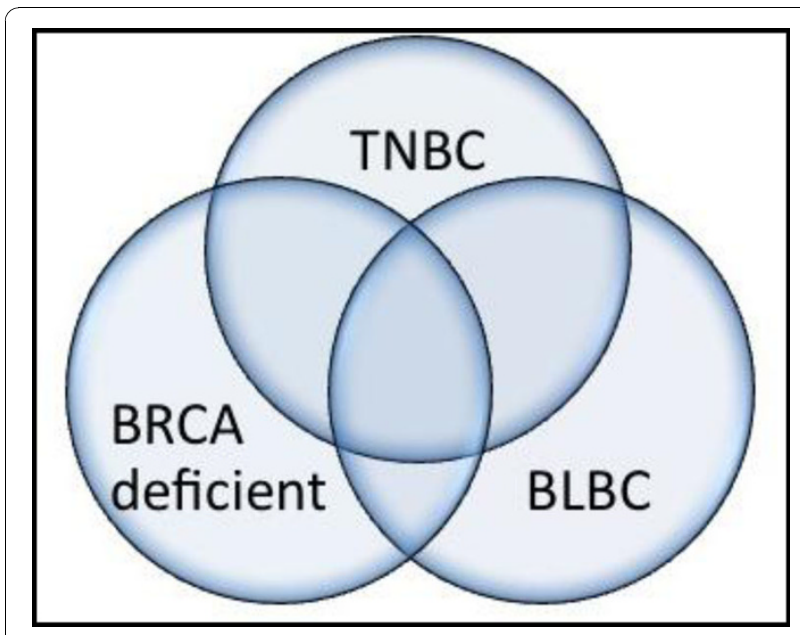

Figure 1 Schematic diagram the represents the significant overlap that exists between triple-negative (TNBC), basal-like breast cancer (BLBC) and breast cancer that arises in patients who have a BRCA mutation. While the majority of cancers that are TNBC are also BLBC. Non-basal triple-negative breast cancer also exists. Similarly most breast cancers that occur in women with BRCA mutations are TNBC and of the BLBC subtype, however this overlap is not complete.

positive disease. In this group the majority (73\%) were luminal (A or B), but $11 \%$ were HER2-enriched, $5 \%$ were basal-like, and $12 \%$ were normal-like [7]. Similarly, in the ER negative group, $11 \%$ of the tumors were found to be luminal, $32 \%$ HER2-enriched, $50 \%$ basal-like, and $7 \%$ normal-like. Their work, and that of others, demonstrated that ER and HER2 status is not an accurate surrogate for true intrinsic subtype status (differentiation between luminal A, luminal B, HER2 and basal-like) [8].

As we wait for validation and further research related to several proposed gene profiles, several investigators have used expression of basal/myoepithelial cell proteins identified by immunohistochemical staining, as a surrogate of gene expression [9-11]. The most widely used panel is based on the expression of cytokeratin $5 / 6$ (CK5/6) and/or the epidermal growth factor receptor (EGFR) in tumors that are triple-negative [12]; however, no uniform consensus exists as to what is the optimal immunnohistochemical panel to identify basal-like breast cancer. Thus TNBC, despite having an imperfect correlation $[9,13,14]$, is generally used clinically as a marker of being a basal-like cancer.

\section{Rationale for the Term Basal-like Breast Cancer}

The normal human breast ducts and acini are composed of two cell layers, which include an inner luminal cell population and a distinct outer cell layer juxtaposed to the basement membrane, named the myoepithelial or basal layer. Cells from each layer have a distinct immunophenotypic profile. Basal-like cancer cells commonly express some of the basal cell markers such as cytokeratin 5 (CK5) and 17 (CK17), as well as caveolin-1, EGFR, B-crystallin, P-cadherin, and c-KIT [15-17]. This does not necessarily imply that basal-like tumors arise from the myoepithelial layer; this area remains the focus of intensive investigation[18].

\section{Clinicopathological Characteristics}

Approximately $15-20 \%$ of breast cancers are TNBC $[19,20]$, the majority of which are from the basal-like subtype. Basal-like cancers are typically associated with a higher histological grade, marked cellular pleomorphism, a high Ki67 index, increase mitotic activity and atypical mitotic figures[9,21-24]. At the genomic level, in comparison with other subtypes, the basal-like subtype is distinguished by genomic instability, an increase in DNA copy number changes, and frequent low-level gains and deletions $[25,26]$. This subtype is also characterized by deregulation of important components of the cell cycle process, such as the $R B$ pathway [27] and frequent $p 53$ abnormalities $[3,21,28]$. Mutations in this gene have been reported in up to $82 \%$ of patients, compared to only $13 \%$ in the luminal A group [3].

\section{Relationship with BRCA-related Cancers}

Patients with germline mutations in the $B R C A$ genes are at risk of developing breast, ovarian, pancreatic, and prostate cancers, among other malignancies. The products of the $B R C A$ genes have a variety of roles, including those relating to DNA-repair mechanisms. Cells that lack a functional $B R C A 1$ or $B R C A 2$ have a deficiency in the repair of DNA double-strand breaks, which is probably one of the mechanisms behind their association with increased cancer predisposition [29]. There are interesting and relevant similarities between cancers that arise in carriers of $B R C A$ gene mutations and basal-like breast cancer that have led to the hypothesis that they share defects of the BRCA or related pathways. When breast cancer arises in patients with $B R C A$ mutations, the majority are triple negative [30], and of the basallike subtype in $80-90 \%$ of the cases [2,31-33]. BRCA1related cancers similar to basal-like breast cancers tend to be characterized by a high frequency of $p 53$ mutations [3,34] and genomic instability [26,32].

Mutations in the BRCA genes are found to be rare in sporadic breast cancers [35,36], however, recent studies have suggested that alteration in the expression or function of these or related DNA-pathway repair genes is important in the development of sporadic breast cancer [32]. Methylation of the $B R C A 1$ promoter, which leads to a reduced expression of $B R C A 1$, has been reported to be present in 11 to $14 \%$ of sporadic breast cancers [37,38], where it is associated with a higher histological grade and a triple-negative phenotype [37-39]. In basal-like breast 
cancer, the overexpression of ID4, a negative regulator of $B R C A 1$, appears to also play a significant role in the deregulation of BRCA1 [40], but further studies are needed to confirm these findings. Other genes associated with BRCA1 in DNA repair by homologous recombination, such as RAD51, Fanconi's anemia proteins, CHEK2 and ATM, have also been found to be implicated in breast carcinogenesis. Whether alterations in these genes also have a role in the development of basal-like breast cancer is currently unknown and poses an interesting question for further study.

\section{Patients' Characteristics and Prognosis}

TNBC and basal-like cancers are associated with a younger age at presentation, having a mean age of 53 years old, compared to 58 years old for other subgroups in one study [20]. Race also appears to be a risk factor, as it is more frequent in premenopausal patients of African-American heritage [19,41]. Patients with these subtypes generally present at a similar stage compared to other tumors [19], but appear to have an inferior outcome $[42,43]$. This inferior prognosis has been found to be independent of several other factors such as tumor grade, size and nodal status [44].

Basal-like cancers are characterized by a distinct pattern of metastasis with a predilection to metastasize to brain and lungs and less incidence of metastases to bone, liver and non-regional lymph nodes [45]. Patients with basal-like breast cancer appear have a higher incidence of locoregional failures after initial surgical treatment when compared with Luminal type A patients [46]. Interestingly, in the study by Voduc and colleagues which used IHC to determine subtype, those cancers that were triple-negative and negative for the expression of EGFR and CK5/6 (non-basal triple-negatives), had a lower incidence of locoregional relapse when compared to the basal-like subtype [46].

\section{Therapy}

As stated above, there is no currently accepted specific molecular targeted agent against TNBC; however, they do appear to be responsive to chemotherapy [47]. Posthoc analysis of several studies with diverse chemotherapy agents have shown that it is TNBC patients who seem to benefit the most from cytotoxic agents in the adjuvant setting [48-50]. Similarly, when neoadjuvant chemotherapy is administered, patients with TNBC and HER2 amplification have better response rates, as well as more frequent incidence of a pathological complete response (pCR) [51-53]; as high as $45 \%$ in a study that used 5-fluorouracil (5-FU), doxorubicin and cyclophosphamide [51]. Unfortunately, this does not translate into a better overall survival, mostly because those patients who did not achieve a complete response (CR) tend to relapse sooner than patients with other breast cancer subtypes.

There is no preferred agent in the neoadjuvant setting, although more data are definitely needed related to whether anthracycline/taxane based therapies should remain the standard approach [63].

\section{Platinum Agents}

A group of agents particularly interesting for management of patients with TNBC are the platinum compounds, partially based on their ability to bind directly to DNA. This causes the DNA to crosslink, resulting in double-strand DNA breakage[54,55]. It has been theorized and shown in preclinical models, that neoplastic cells harboring BRCA mutations, and thus lacking one of the mechanisms to repair damaged DNA, are consequently more susceptible to agents that induce DNA damage [56]. A very small retrospective study that included women with $B R C A$ mutations who received neo-adjuvant treatment demonstrated that patients who received cisplatin had a higher degree of pCR $(83 \%$ vs. less than $22 \%$ with other regimens, not including platins) [57]. Although these data are intriguing, they should be taken with caution as the study only had 12 patients in the cisplatin cohort and it was retrospective.

In the neoadjuvant setting, single agent cisplatin was evaluated in 28 patients with TNBC which led to a pCR in six (22\%) women[58]. This same group of investigators conducted a separate neoadjuvant study, this time adding bevacizumab to cisplatin. Preliminary results indicated that this combination led to a pCR in 15\% (7 out of 46 patients) [59]. These results are somewhat disappointing, as the proportions of complete responses are significantly less than that achieved with multiagent neoadjuvant chemotherapy (30 - 45\% in other studies) [51,52]. Because of the biochemical similarities between BRCA related breast cancers and TNBC, it has been hypothesized that TNBCs are also specifically sensitive to platinum agents. This remains a controversial topic, as to date there is no randomized, controlled study that has demonstrated the benefit of platinum versus other agents.

Cisplatin has also been coupled with other cytotoxic agents for neoadjuvant treatment; when used with epirubicin and 5-FU a pCR of $40 \%$ was achieved [60]. In a similar study of 74 patients treated with cisplatin, epirubicin and paclitaxel with G-CSF support, a remarkably high rate of pCR (65\%) was seen [61]. These are encouraging results that merit further validation and testing. At the current time, however, platinum agents in the neoadjuvant setting cannot be recommended over established regimens outside of a clinical trial. Two current neoadjuvant randomized studies should help clarify the role of platinum agents in the these situations, 
CALGB40603 (described below in the bevacizumab section), and a Spanish Breast Cancer Research Group study [62]. In both of these trials, patients will be randomized to receive carboplatin as part of their preoperative treatment, in the Spanish study patients will receive epirubicin and cyclophosphamide for 4 cycles and then be randomized to receive docetaxel or carboplatin (NCT00432172).

In patients with metastatic disease, two clinical trials will help clarify the role of platinum agents. First, the Phase II Translational Breast Cancer Research Consortium 009 trial (NCT00483223) is evaluating the response rate of metastatic breast cancer patients treated with cisplatin or carboplatin. This trial will also evaluate, prospectively, the expression of $p 63 / p 73$ as a potential biomarker of platinum sensitivity. These proteins are part of the $p 53$ family. They are expressed in approximately one-third of patients with TNBC, and their coexpression in breast cancer cell lines results in 10-fold to 100 -fold greater sensitivity to platinum chemotherapy [63]. The second study is a phase III trial currently underway in the UK, which will randomize 400 women with TNBC to carboplatin or docetaxel with crossover at progression (NCT00532727).

\section{Anti-tubulin Agents}

A new agent that has recently been added to the armamentarium of drugs available for the treatment of breast cancer is ixabepilone. Similar to taxanes, ixabepilone stabilizes microtubules and causes cell cycle arrest and apoptosis [64]. It has the advantage of bypassing the resistance mechanisms associated with drug efflux pumps and specific paclitaxel resistance associated with $\beta$-tubulin [64]. Its use has been studied as a single agent in four distinct clinical trials that included 288 patients, of whom 113 (39\%) had TNBC. Two phase III clinical trials have also compared ixabepilone coupled with capecitabine versus capecitabine alone. A subset analysis of women with TNBC identified an improved overall response for this combination of $31 \%$ versus $15 \%$ and a progression free survival (PFS) of 4.2 months versus 1.7 months (HR 0.63; 95\% CI 0.52-0.77) [65]. In the neoadjuvant setting, treatment with ixabepilone led to a $\mathrm{pCR}$ in $26 \%$ of the 42 women with TNBC [66]. A retrospective analysis of this study analyzed the expression of $\beta I I I-$ tubulin, a $\beta$-tubulin, whose expression is correlated with resistance to taxanes. Patients with a basal-like phenotype had a higher expression of $\beta$ III-tubulin, and its expression was predictive of response to therapy in the overall population (area under the curve of 0.66) [67]. Further studies of the potential role of this as a predictive marker are needed before conclusions can be reached.

Another novel mitotic inhibitor currently being studied for the treatment of breast cancer is eribulin. A recently reported phase III trial compared eribulin against several investigator-chosen regimens for the treatment of women with refractory metastatic breast cancer. An improved survival in favor of those women taken eribulin was demonstrated (Median OS was 13.1 vs. 10.7, HR 0.81; 95\% CI 0.66-0.99) [68]. Of the patients enrolled in this trial, $20 \%$ had TNBC. The subset analysis for this trial has not been yet reported.

\section{Targeted Therapies}

Poly(ADP)ribose polymerase 1 (PARP1) is a nuclear protein that is recruited to the site of damage after the induction of both single and double stranded DNA breaks. PARP1 catalyzes the transfer of ADP-ribose polymers from NAD+ to target proteins, which in turn modulate DNA restoration by activating and recruiting important components of base excision repair pathway, such as XRCC1 [69,70]. PARP1 also contributes to the modification of histones, which leads to local chromatin remodeling, allowing access of DNA repair proteins to the repair site [71]. The inhibition of PARP1 potentiates the effects of ionizing radiation, DNA methylating agents, topoisomerase I inhibitors, and platinum compounds [70,72]. When PARP1 is inhibited in normal cells, DNA repair is done through the homologousrecombination pathway, a process for which $B R C A$ is a key factor [73]. Cells that are deficient in $B R C A$ are more dependent on PARP1 to maintain genomic integrity. Its inhibition thus leads to synthetic lethality $[32,74,75]$, a process that occurs when inactivation of either of the two genes individually has no effect but combining the mutations is deadly to the cell $[69,73]$. Several PARP1 inhibitors are at different stages of clinical development, olaparib (previously known as AZD2281) has been evaluated in a phase 1 study where 60 patients with breast cancer were enrolled, of these, nine patients had an objective response. In addition, all the responders had abnormalities in one of the $B R C A$ genes. Of the women with breast cancer, three had a BRCA2 mutation. A complete response that lasted in excess of 60 weeks also occurred in one of the BRCA carriers and another one had stable disease for 7 months. Olaparib was further evaluated in a phase II study that enrolled 54 patients with known BRCA mutations and breast cancer. The first 27 women enrolled received $400 \mathrm{mg}$ twice per day, of which 11 (41\%) experienced a response with a median PFS of 5.7 months. A second cohort of 27 women received $100 \mathrm{mg}$ of olaparib twice per day (the lowest dose that showed an active pharmacodynamic profile in the phase 1 study). In this group, 6 patients (22\%) experienced a response with a median PFS of 3.8 months. This agent was fairly well tolerated, with nausea and fatigue being the most common adverse events[76]. A recent phase I 
study reported by Dent et al. at the 2010 American Society of Clinical Oncology (ASCO) meeting demonstrated that it was not feasible to administer the $200 \mathrm{mg}$ daily dose of olaparib in combination with weekly paclitaxel due to significant myelosuppression, in spite of prophylaxis with growth factor support [77]. Several clinical trials using olaparib in women with BRCA deficient cancers are in different stages of development (see table 1)

The similarities described above between the breast cancers that arise in patients with $B R C A$ mutations and basal-like cancer have led to the hypothesis that a deficiency in a component of the $B R C A$ pathway plays an important role in basal-like cancers, thus inhibition of PARP1 could also be an important therapeutic strategy. In a phase 2 study, 120 patients were randomized (1:1) to gemcitabine and carboplatin alone or the same combination plus the intravenous PARP1 inhibitor, iniparib (BSI-201). Gemcitabine $\left(1000 \mathrm{mg} / \mathrm{m}^{2}\right.$; IV) and carboplatin $(\mathrm{AUC}=2$; IV) were given on days 1 and 8 , and iniparib $(5.6 \mathrm{mg} / \mathrm{kg}$; IV) on days $1,4,8$, and 11 every 21 days. The addition of iniparib led to an improved response rate, $(16 \%$ vs. $48 \% ; \mathrm{p}=0.002)$ as well as PFS (3.3 vs. 6.9 months; $\mathrm{p}<0.0001$ ) and overall survival (12.2 vs. 7.7 months; $\mathrm{p}=0.005 ; \mathrm{HR}=0.5 ; 95 \% \mathrm{CI}, 0.30$ - 0.82)[78-80]. The addition of iniparib was well tolerated, with no evidence of neither incremental nor new adverse effects compared to the standard arm. A confirmatory phase III clinical trial using the same regimen has completed accrual in February 2010, with data expected in 2011(NCT00938652). Iniparib is also being evaluated in 2 neoadjuvant clinical trials, NCT00813956 is a single arm trial that is studying the combination of iniparib, carboplatin and gemcitabine. The other one is a Spanish study in which patients will be randomize to received either iniparib plus paclitaxel versus placlitaxel alone (NCT01204125).

Veliparib (ABT-888) is another PARP1 inhibitor being evaluated in breast cancer. A recently reported study where it was used with temozolamide enrolled 41 women with metastatic disease, of which 23 (56\%) had TNBC. The dose of veliparib was reduced from $40 \mathrm{mg}$ to $30 \mathrm{mg}$ BID due to thrombocytopenia encountered during the first cycle. In this study the activity of this combination was limited to those women who were deficient for BRCA1 (1 partial response (PR)) and BRCA2 ( $1 \mathrm{CR}$ and $1 \mathrm{PR}$ ). Stable disease lasting more than 4 months was seen in 4 patients, 2 of who had a BRCA2 mutation. Median PFS was 1.9 months in all patients and 5.5 months in those with $B R C A$ mutations[81].

It is intriguing why patients treated with oral PARP1 inhibitors had increased toxicity when these agents were used with cytotoxic chemotherapy when in contrast those patients treated with iniparib, an IV PARP1 inhibitor, had no increase toxicity.

Of note is that several studies suggest that PARP1 inhibitors may also be beneficial in other subtypes of breast cancer beyond TNBC. Analysis of PARP1 expression via IHC was done in tissue microarrays from core biopsies of 582 patients recruited to the phase III taxane-anthracycline neoadjuvant, GeparTrio trial. PARP1 expression was found to be present in $20 \%$ of patients with hormone receptor positive tumors, $34.4 \%$ of

Table 1 Active Clinical Trials with the 3 most developed PARP1 inhibitors

\begin{tabular}{|c|c|c|}
\hline Number & Population studied & Description \\
\hline \multicolumn{3}{|l|}{ Olaparib } \\
\hline NCT01116648 & Metastatic TNBC & Phase I/II study to evaluate optimal drug dose and establish activity of cediranib and olaparib. \\
\hline NCT01078662 & BRCA associated breast cancer & Phase II in patients with BRCA related cancers \\
\hline NCT01115829 & Metastatic TNBC & $\begin{array}{l}\text { Phase } 1 \text { of the combination of cediranib plus olaparib followed by a randomized phase } 2 \text { that } \\
\text { evaluates cediranib with or without olaparib. }\end{array}$ \\
\hline NCT00516724 & Metastatic TNBC & $\begin{array}{l}\text { Multi-arm Phase I study that evaluates the safety and efficacy of the combination of olaparib with } \\
\text { carboplatin, olaparib with paclitaxel or olaparib with carboplatin and paclitaxel. }\end{array}$ \\
\hline NCT00647062 & $\begin{array}{l}\text { Metastatic TNBC or BRCA } \\
\text { associated breast cancer }\end{array}$ & Phase 1 of the combination of olaparib and carboplatin \\
\hline \multicolumn{3}{|l|}{ Veliparib } \\
\hline NCT01104259 & $\begin{array}{l}\text { Metastatic TNBC or BRCA } \\
\text { associated cancer }\end{array}$ & Phase I study of the combination of veliparib, vinorelbin and cisplatin \\
\hline NCT01149083 & BRCA associated breast cancer & Randomized phase 2 evaluating veliparib with or without carboplatin. \\
\hline NCT01042379 & Neoadjuvant TNBC & $\begin{array}{l}\text { Multi-arm study that evaluates several regimens, One arm contains the combination of paclitaxel, } \\
\text { carboplatin and veliparib }\end{array}$ \\
\hline \multicolumn{3}{|l|}{ Iniparib } \\
\hline NCT00813956 & Neoadjuvant TNBC & Phase 2 study of the combination of gemcitabine, carboplatin and iniparib. \\
\hline NCT01204125 & Neoadjuvant TNBC & Randomized phase 2 study of paclitaxel with or without iniparib \\
\hline NCT01173497 & TNBC with brain metastasis & Phase 2 study of iniparib and irinotecan in women with CNS metastasis. \\
\hline
\end{tabular}


hormone receptor negative and HER2 positive tumors and $34.2 \%$ of TNBC. A high PARP1 expression was associated with higher incidence of pCR (26.5\%) in patients in with high PARP1 expression compared to $19.1 \%$ and $8.9 \%$ in patients with medium or low expression respectively $(\mathrm{p}<0.0005)$ [82]. Another clue that PARP1 inhibition might be beneficial in other breast cancer subtypes relates to its relationship with phosphatase and tensin homolog (PTEN), a phosphatase that contributes to the regulation of cell cycle progression, cell proliferation and DNA repair. Cell lines deficient in PTEN have an impaired homologous DNA recombination and increased cytotoxicity with PARP1 inhibition both in vitro and in vivo An estimated $50 \%$ of breast cancers, irrespective of their triple-receptor negativity, have a mutation in, or loss of, at least one copy of the PTEN gene $[83,84]$. Lastly, deregulation of DNA repair mechanisms and genomic instability is not exclusive of triple-negative or basal-like breast cancers, and is also commonly present in Luminal B and HER2 amplified tumors [85]. Whether using a PARP1 inhibitor will lead to synthetic lethality in other breast cancer subtypes is an intriguing question that is worth exploring.

The use of PARP1 inhibitors is at its infancy and many questions remain, such as the following: Which patients are most likely to benefit from this therapy? Are there any biomarkers that predict response to PARP1 inhibition besides $B R C A$ mutations? What are the best cytotoxic agents to use with PARP1 inhibitors? What are the mechanisms of resistance to these therapies? Should PARP1 inhibitors be continued upon progression of the disease when introducing another cytotoxic agent? To answer such questions, new translational clinical trials are being designed and conducted.

\section{Other Targeted Agents}

Some studies suggest that TNBC expresses EGFR in nearly half of the cases $[9,21]$. Its expression is found to be associated with an inferior outcome. A phase II study randomized patients to receive either cetuximab, an EGFR monoclonal antibody, alone followed by carboplatin upon progression versus concomitant cetuximab and carboplatin. Cetuximab by itself has little activity as a single agent with only 2 of 31 patients achieving a PR. When used in combination with carboplatin, it led to a PR in 13 patients and overall clinical benefit $(\mathrm{CR}+\mathrm{PR}+$ Standard disease for more than 6 months) in 19 of the 71 patients enrolled [86]. In a separate randomized phase II study, the addition of cetuximab to irinotecan and carboplatin increased RR from $30 \%$ to $49 \%$ [87]. Samples from patients enrolled in both of these trials are being studied to identify biomarkers that correlate with response to this agent [88]. A fully humanized antibody against $E G F R$, panitumumab [89], is currently being evaluated in combination with gemcitabine and carboplatin in TNBC (NCT00894504). Another approach to inhibit EGFR receptor signaling is with the use of small molecules that inhibit the tyrosine kinase domain of this receptor. Erlotinib, an agent of this kind, is currently being evaluated in combination with docetaxel and carboplatin in patients with metastatic TNBC (NCT00491816).

The $S R C$ tyrosine kinase is a non-receptor signaling kinase that functions downstream of several growth factor receptors including PDGFR, EGFR, IGF-1R, and $H G F R$. It plays an important role in cancer cell proliferation and invasion through multiple pathways $[90,91]$. $S R C$ has been found to be deregulated in breast cancer $[92,93]$ making it a potentially important therapeutic target. Using gene expression profiling of breast cancer cell lines, two groups independently identified a gene expression pattern that was predictive of sensitivity to dasatinib, a mutitargeted thyrosine kinase that targets important oncogenic pathways, including the $S R C$ family kinases $[94,95]$. This gene signature was present more commonly in both cell lines and in patients who had a triple-negative profile. However, dasatinib has now been studied as a single agent in TNBC with disappointing results, with only two out of 43 patients achieving a PR [96]. A currently ongoing study (NCT00780676) is evaluating whether a gene expression pattern, if present, can predict a response to dasatinib as a single agent in different subsets of breast cancers [97].

\section{Anti-angiogenic Agents}

Angiogenesis is required for tumor growth, invasion and metastasis in several malignancies, including breast cancer. This process can be targeted with therapeutic purposes through several mechanisms. The vascular endothelial growth factor (VEGF) is a key mediator of angiogenesis. Its intratumoral expression has been found to be markedly elevated in patients with TNBC, compared to other subtypes [98]. Bevacizumab, a humanized monoclonal antibody against VEGF-A, has proven to be a valuable agent in metastatic breast cancer in several phase III clinical trials. In the E2100 study that evaluated this agent along with paclitaxel, patients who were randomized to the bevacizumab arm had an improved overall response rate of $48 \%$ versus $33 \%$ in those who received paclitaxel alone. The median PFS was significantly longer in those who received bevacizumab (11.4 versus 5.8 months, hazard ratio, $0.42 ; \mathrm{P}<0.0001$ ), but the overall survival rate was similar in both groups (median, 26.7 vs. 25.2 months; hazard ratio, 0.88 ; $\mathrm{p}=$ 0.16)[99]. TNBC was present in 233 of the 763 (31\%) patients enrolled in the E2100 trial. In this group, the PFS was increased to 10.2 months compared to 4.7 months in the paclitaxel alone arm $(\mathrm{HR}=0.45 ; 95 \%, \mathrm{CI}$, 0.33-0.61) [100]. The AVADO trial evaluated docetaxel 
alone or with two different doses of bevacizumab (7.5 and $15 \mathrm{mg} / \mathrm{kg}$ every 3 weeks). Compared to placebo, PFS was superior in both bevacizumab arms, the $15 \mathrm{mg} /$ $\mathrm{kg}$ arm was more favorable than the $7.5 \mathrm{mg} / \mathrm{kg}$ arm (median 10.0 months $(15 \mathrm{mg} / \mathrm{kg}), \mathrm{HR}=0.67 ; \mathrm{P}=0.0002$ and 9.0 months $(7.5 \mathrm{mg} / \mathrm{kg}), \mathrm{HR}=0.80 ; \mathrm{P}=0.0450$ versus 8.1 months in the docetaxel alone arm) [101]. There were 167 women with TNBC (22\%), in this subgroup the addition of bevacizumab at $15 \mathrm{mg} / \mathrm{kg}$ led to an improvement in PFS from 6.0 to 8.1 months (HR = 0.60, 95\%; CI, 0.39-0.92) [100]. This occurred even though the design of this study did not take full advantage of the interaction of chemotherapy plus bevacizumab, as the docetaxel was only used for a pre-set number of cycles per patient.

The RIBBON-1 trial proved that bevacizumab increased PFS and overall response rate when compared to placebo when this agent was used with single agent taxanes, anthracycline-based regimes, and capecitabine [102]. A subset analysis of patients with TNBC demonstrated an improvement in PFS when bevacizumab was used both with capecitabine ( 6.1 vs. 4.2 months, $\mathrm{HR}=$ $0.72,95 \% \mathrm{CI}, 0.49-1.06)$. This was also found in the taxane/anthracycline cohort ( 8.2 to 14.5 months, $\mathrm{HR}=0.78$, 95\% CI, 0.53-1.15) [100]. A recently reported meta analysis of these 3 trials showed, as expected, a PFS advantage for patients on bevacizumab ( $\mathrm{HR}=0.64,95 \% \mathrm{CI}, 0.58$ $0.71)$ [103]. This was also true in a subset analysis of patients with TNBC $(\mathrm{HR}=0.63,95 \% \mathrm{CI}, 0.52-0.76)$. However, no survival advantage was seen in the whole population or in those with triple-negative disease, which may be partially explained by the fact that there was a $60 \%$ crossover to adding bevacizumab for patients who developed tumor progression after receiving chemotherapy plus placebo. Moreover, it is important to document that this meta-analysis did demonstrate a statistically significant improvement in one-year survival for patients assigned to chemotherapy and bevacizumab versus chemotherapy and placebo. Bevacizumab is currently being evaluated in TNBC by several independent studies. CALGB 40603 (NCT00861705) is a phase II neoadjuvant study in which patients will undergo two randomizations in order to receive paclitaxel with or without carboplatin and this combination with or without bevacizumab. The second study, BEATRICE (NCT00528567) is a phase III adjuvant study where several chemotherapy regimens and different doses of bevacizumab are being evaluated in patients with TNBC. This trial recently completed accrual and the results are eagerly awaited.

\section{Other Antiangiogenic and Multikinase Inhibitors}

Another multikinase inhibitor with antiangiogenic properties, sunitinib, has been evaluated as a single agent in a phase II study, where it was found to induce a response in $11 \%$ of a heavily pretreated cohort of metastatic breast cancer patients [104]. Unfortunately, two phase III studies have now shown that combining sunitinib with docetaxel or capecitabine does not offer any benefit in prolonging PFS compared to the cytotoxic regimen alone in patients with advanced breast cancer $[105,106]$. This agent is currently being evaluated in addition to carboplatin and paclitaxel as adjuvant treatment for TNBC (NCT00887575).

The mammalian target of rapamycin (mTOR) is a protein that is downstream of the PI3K/AKT pathway and, when activated, promotes protein synthesis and angiogenesis [107]. Everolimus, an mTOR inhibitor, has a $12 \%$ overall RR when used as a single agent in heavily pretreated patients with metastatic breast cancer [108]. It is currently being evaluated as a single agent in a phase II clinical trial in patients with metastatic TNBC (NCT00827567), and in a placebo controlled neoadjuvant randomized phase II study along with cisplatin and paclitaxel in patients with stages II and III TNBC (NCT00930930).

\section{Therapy Based on the Androgen Receptor}

In an effort to further study the heterogeneity of TNBC, Doane and colleagues [109] conducted a genome wide gene expression profiling study of 99 patients with breast cancer, 41 of whom had triple negative disease. They noticed that nine of the patients with TNBC clustered together with the ER positive group. When focusing on only those patients with TNBC, the nine ERdiscordant samples closely correlated with each other and were contained in a single cluster with only one additional case. Further characterization of this subtype of TNBC showed that it had a molecular resemblance to ER positive tumors and expressed genes that are targets of the ER. Half of the tumors in this group expressed the androgen receptor. Subsequently, these investigators identified MDA-MB-453 as a cell line that had a molecular phenotype similar to the previously described subtype of TNBC. This cell line, as expected, did not respond to estrogen administration but in contrast had a proliferative effect with androgen stimulation in an ER-independent but AR-dependent manner. Several studies have established that between $10-35 \%$ of TNBC express the androgen receptor [110-112]. These, and other, preclinical data have given support to the development of a phase II trial using bicalutamide, an antiandrogen, in the treatment of TNBC that are androgen receptor positive (NCT00468715).

\section{Other Targets}

New studies that utilize high throughput technologies to assess gene expression and genomic copy number variations have provided insight into the heterogeneity of 
TNBC and have successfully identified potential new targets [113]. Among the targets is the fibroblast growth receptor $(F G F R)$, which is part of an important signaling pathway found to be deregulated in several malignancies [114]. FGFR1 is overexpressed in up to $5.5 \%$ of patients with TNBC [115]. The FGFR2 gene has alleles that have been associated with risk of developing postmenopausal breast cancer [116]. This gene has also been found to be overexpressed in $5 \%$ of patients with TNBC[114]. Several tyrosine kinase inhibitors that target the FGFR receptor are currently in different stages of development [114]. One of these agents, TKI258, is currently being evaluated in a phase II study of women with HER2 negative breast cancer (NCT00958971).

Another potential target is the RAS-mitogen activated protein kinase (MAPK) signaling pathway, as it plays a central role in regulating the growth and survival of neoplastic cells. The inhibition of this pathway has been a sought after target in cancer drug development for several years. Several inhibitors of the mitogen-activated protein kinase $(M E K)$, an essential component of this pathway, are in clinical trials for multiple malignancies including breast cancer [117]. Preclinical studies have demonstrated that the inhibition of $M E K$ leads to the activation of the phosphatidylinositol 3-kinase (PI3K) pathway, a pathway that is also found to be deregulated in $30 \%$ of patients with basal-like breast cancer $[84,118]$. This feedback counteracts the effects of $M E K$ inhibition on cell cycle and apoptosis induction $[119,120]$. Dual blockade, with inhibitors of both PI3K and $M E K$, synergistically inhibits growth of basal-like breast cancer cells in vitro and in vivo $[119,120]$. This combination needs to be evaluated in women with TNBC.

Finally, Speers and colleagues have used transcriptional profiling data to evaluate the expression of the human kinome. They were able to identify a set of kinases differentially expressed and critical for the growth of ER negative breast cancer [121]. In this study, two groups of TNBC were identified, a subset defined by kinases involved in cell cycle checkpoint control and mitogenesis such as $C H K 1, B U B 1, T T K$, and $A K 2$ and another subset defined by kinases involved in the $\mathrm{S} 6$ kinase-signaling pathway, which includes the RPS6KA3,SMG-1, and RPS6KA1 kinases. The authors performed siRNA knockdown experiments to downregulate the expression of several of the kinases of interest and established that of the 20 kinases evaluated, 14 were critical for the growth of ER-negative breast cancer cell lines. The majority of these kinases are "druggable" targets that could be potentially used for therapeutic purposes.

\section{Conclusion}

TNBC, of which the majority of cases belong to the basal-cell like phenotype of breast cancer, is a heterogeneous group. Although very likely to change in the near future, at this time, we still recommend the combination of doxorubicin plus cyclophosphamide followed by paclitaxel for patients with TNBC, in the adjuvant setting. For patients with metastatic disease, there is no standard first line agent to recommend, although the results of the ongoing phase III trial of iniparib may change the recommended standard of care, therapy should be individualized for each patient and enrollment into clinical trials is strongly encouraged. Established agents such as platinums, ixabepilone, and the antiangiogenic monoclonal antibody bevacizumab are under evaluation in both the adjuvant and the metastatic setting. The result of studies using new agents, such as inhibitors of PARP1, tyrosine kinases, and mTOR are currently in different phases of development and will hopefully change the paradigm of how we treat patients affected with TNBC. As new discoveries are being made, current clinical trials have translational components that we expect will provide biomarkers useful to effectively discriminate patients into those who are more likely to respond to certain therapies. The use of newer molecular techniques have and will continue to be very valuable in indentifying potential new molecules important for survival of neoplastic cells and that could potentially be targeted in the treatment of women with TNBC.

\section{List of abbreviations}

ASCO: American Society of Clinical Oncology; CK: Cytokeratin; EGFR: epidermal growth factor receptor; ER: Estrogen Receptors; 5-FU: 5fluorouracil; FISH: fluorescence in situ hybridization; HER2: human epidermal growth factor receptor 2; IHC: Immunohistochemistry; PgR: Progesterone Receptors; TNBC: Triple-negative Breast Cancer; CR: complete response; PR: partial response.

\section{Author details}

'Division of Neoplastic Diseases and Related Disorders Medical College of Wisconsin, 9200 W. Wisconsin Ave, Milwaukee, WI 53226 USA. ${ }^{2}$ Division of Hematology and Oncology Mayo Clinic, 4500 San Pablo Road, Jacksonville, Florida. 32224. USA.

\section{Authors' contributions}

RSD and EAP both made substantial contributions to conception and design, have both been involved in the drafting of the manuscript and both have given final approval of the version to be published.

\section{Competing interests}

Dr. Rafael Santana-Davila has no competing interest. Dr. Edith A. Perez has research funding from Genentech, Sanofi-Aventis, and Roche.

Received: 22 July 2010 Accepted: 27 October 2010

Published: 27 October 2010

\section{References}

1. Jemal A, Siegel R, Ward E, Hao Y, Xu J, Thun MJ: Cancer statistics, 2009. CA Cancer J Clin 2009, 59:225-249.

2. Sorlie T, Tibshirani R, Parker J, Hastie T, Marron JS, Nobel A, Deng S, Johnsen H, Pesich R, Geisler S, et al: Repeated observation of breast tumor subtypes in independent gene expression data sets. Proc Natl Acad Sci USA 2003, 100:8418-8423. 
3. Sorlie T, Perou CM, Tibshirani R, Aas T, Geisler S, Johnsen H, Hastie T, Eisen MB, van de Rijn M, Jeffrey SS, et al: Gene expression patterns of breast carcinomas distinguish tumor subclasses with clinical implications. Proc Natl Acad Sci USA 2001, 98:10869-10874.

4. Perou CM, Sorlie T, Eisen MB, van de Rijn M, Jeffrey SS, Rees CA, Pollack JR, Ross DT, Johnsen $H$, Akslen LA, et al: Molecular portraits of human breast tumours. Nature 2000, 406:747-752

5. Hu Z, Fan C, Oh DS, Marron JS, He X, Qaqish BF, Livasy C, Carey LA, Reynolds $E$, Dressler $L$, et al: The molecular portraits of breast tumors are conserved across microarray platforms. BMC Genomics 2006, 7:96.

6. Sotiriou C, Pusztai L: Gene-expression signatures in breast cancer. N Engl J Med 2009, 360:790-800.

7. Parker JS, Mullins M, Cheang MC, Leung S, Voduc D, Vickery T, Davies S, Fauron C, He X, Hu Z, et al: Supervised risk predictor of breast cancer based on intrinsic subtypes. J Clin Oncol 2009, 27:1160-1167.

8. Weigelt B, Mackay A, A'Hern R, Natrajan R, Tan DS, Dowsett M, Ashworth A, Reis-Filho JS: Breast cancer molecular profiling with single sample predictors: a retrospective analysis. Lancet Oncol 2010, 11:339-349.

9. Nielsen TO, Hsu FD, Jensen K, Cheang M, Karaca G, Hu Z, HernandezBoussard T, Livasy C, Cowan D, Dressler L, et al: Immunohistochemical and clinical characterization of the basal-like subtype of invasive breast carcinoma. Clin Cancer Res 2004, 10:5367-5374

10. Banerjee S, Reis-Filho JS, Ashley S, Steele D, Ashworth A, Lakhani SR, Smith IE: Basal-like breast carcinomas: clinical outcome and response to chemotherapy. J Clin Pathol 2006, 59:729-735.

11. Rakha EA, El-Sayed ME, Green AR, Paish EC, Lee AH, Ellis IO: Breast carcinoma with basal differentiation: a proposal for pathology definition based on basal cytokeratin expression. Histopathology 2007, 50:434-438.

12. Cheang MC, Voduc D, Bajdik C, Leung S, McKinney S, Chia SK, Perou CM, Nielsen TO: Basal-like breast cancer defined by five biomarkers has superior prognostic value than triple-negative phenotype. Clin Cancer Res 2008, 14:1368-1376.

13. Bertucci F, Finetti P, Cervera N, Esterni B, Hermitte F, Viens P, Birnbaum D: How basal are triple-negative breast cancers? International Journal of Cancer 2008, 123:236-240.

14. Rakha EA, Tan DS, Foulkes WD, Ellis IO, Tutt A, Nielsen TO, Reis-Filho JS: Are triple-negative tumours and basal-like breast cancer synonymous? Breast Cancer Res 2007, 9:404, author reply 405.

15. Rakha EA, Elsheikh SE, Aleskandarany MA, Habashi HO, Green AR, Powe DG, El-Sayed ME, Benhasouna A, Brunet JS, Akslen LA, et al: Triple-negative breast cancer: distinguishing between basal and nonbasal subtypes. Clin Cancer Res 2009, 15:2302-2310.

16. Turner N, Lambros MB, Horlings HM, Pearson A, Sharpe R, Natrajan R, Geyer FC, van Kouwenhove M, Kreike B, Mackay A, et al: Integrative molecular profiling of triple negative breast cancers identifies amplicon drivers and potential therapeutic targets. Oncogene 2010, 29:2013-2023.

17. Weigelt B, Reis-Filho JS: Histological and molecular types of breast cancer: is there a unifying taxonomy? Nat Rev Clin Oncol 2009, 6:718-730.

18. Stingl J, Caldas C: Molecular heterogeneity of breast carcinomas and the cancer stem cell hypothesis. Nat Rev Cancer 2007, 7:791-799.

19. Carey LA, Perou CM, Livasy CA, Dressler LG, Cowan D, Conway K, Karaca G, Troester MA, Tse CK, Edmiston S, et al: Race, breast cancer subtypes, and survival in the Carolina Breast Cancer Study. JAMA 2006, 295:2492-2502.

20. Dent R, Trudeau M, Pritchard KI, Hanna WM, Kahn HK, Sawka CA, Lickley LA, Rawlinson E, Sun P, Narod SA: Triple-negative breast cancer: clinical features and patterns of recurrence. Clin Cancer Res 2007, 13:4429-4434.

21. Rakha EA, El-Sayed ME, Green AR, Lee AH, Robertson JF, Ellis IO: Prognostic markers in triple-negative breast cancer. Cancer 2007, 109:25-32.

22. Livasy CA, Karaca G, Nanda R, Tretiakova MS, Olopade OI, Moore DT, Perou CM: Phenotypic evaluation of the basal-like subtype of invasive breast carcinoma. Mod Pathol 2006, 19:264-271.

23. Rakha EA, Putti TC, Abd El-Rehim DM, Paish C, Green AR, Powe DG, Lee AH, Robertson JF, Ellis IO: Morphological and immunophenotypic analysis of breast carcinomas with basal and myoepithelial differentiation. J Pathol 2006, 208:495-506

24. Dawson SJ, Provenzano E, Caldas C: Triple negative breast cancers: clinical and prognostic implications. Eur J Cancer 2009, 45(Suppl 1):27-40.

25. Chin K, DeVries S, Fridlyand J, Spellman PT, Roydasgupta R, Kuo WL, Lapuk A, Neve RM, Qian Z, Ryder T, et al: Genomic and transcriptional aberrations linked to breast cancer pathophysiologies. Cancer Cell 2006, 10:529-541.
26. Andre F, Job B, Dessen P, Tordai A, Michiels S, Liedtke C, Richon C, Yan K, Wang B, Vassal G, et al: Molecular characterization of breast cancer with high-resolution oligonucleotide comparative genomic hybridization array. Clin Cancer Res 2009, 15:441-451.

27. Gauthier ML, Berman HK, Miller C, Kozakeiwicz K, Chew K, Moore D, Rabban J, Chen YY, Kerlikowske K, Tlsty TD: Abrogated response to cellular stress identifies DCIS associated with subsequent tumor events and defines basal-like breast tumors. Cancer Cell 2007, 12:479-491.

28. Troester MA, Herschkowitz JI, Oh DS, He X, Hoadley KA, Barbier CS, Perou CM: Gene expression patterns associated with p53 status in breast cancer. BMC Cancer 2006, 6:276.

29. Narod SA, Foulkes WD: BRCA1 and BRCA2: 1994 and beyond. Nat Rev Cancer 2004, 4:665-676

30. Foulkes WD, Metcalfe K, Sun P, Hanna WM, Lynch HT, Ghadirian P, Tung N, Olopade Ol, Weber BL, McLennan J, et al: Estrogen receptor status in BRCA1- and BRCA2-related breast cancer: the influence of age, grade, and histological type. Clin Cancer Res 2004, 10:2029-2034.

31. Lakhani SR, Reis-Filho JS, Fulford L, Penault-Llorca F, van der Vijver M, Parry S, Bishop T, Benitez J, Rivas C, Bignon YJ, et al: Prediction of BRCA1 status in patients with breast cancer using estrogen receptor and basal phenotype. Clin Cancer Res 2005, 11:5175-5180.

32. Turner N, Tutt A, Ashworth A: Hallmarks of 'BRCAness' in sporadic cancers. Nat Rev Cancer 2004, 4:814-819.

33. Foulkes WD, Stefansson IM, Chappuis PO, Begin LR, Goffin JR, Wong N, Trudel M, Akslen LA: Germline BRCA1 mutations and a basal epithelial phenotype in breast cancer. J Natl Cancer Inst 2003, 95:1482-1485.

34. Hartman AR, Ford JM: BRCA1 and p53: compensatory roles in DNA repair. J Mol Med 2003, 81:700-707.

35. Futreal PA, Liu Q, Shattuck-Eidens D, Cochran C, Harshman K, Tavtigian S, Bennett LM, Haugen-Strano A, Swensen J, Miki Y, et al: BRCA1 mutations in primary breast and ovarian carcinomas. Science 1994, 266:120-122.

36. Teng DH, Bogden R, Mitchell J, Baumgard M, Bell R, Berry S, Davis T, Ha PC, Kehrer R, Jammulapati $S$, et al: Low incidence of BRCA2 mutations in breast carcinoma and other cancers. Nat Genet 1996, 13:241-244.

37. Esteller M, Silva JM, Dominguez G, Bonilla F, Matias-Guiu X, Lerma E, Bussaglia E, Prat J, Harkes IC, Repasky EA, et al: Promoter hypermethylation and BRCA1 inactivation in sporadic breast and ovarian tumors. J Natl Cancer Inst 2000, 92:564-569.

38. Catteau A, Harris WH, Xu CF, Solomon E: Methylation of the BRCA1 promoter region in sporadic breast and ovarian cancer: correlation with disease characteristics. Oncogene 1999, 18:1957-1965.

39. Rice JC, Ozcelik H, Maxeiner P, Andrulis I, Futscher BW: Methylation of the BRCA1 promoter is associated with decreased BRCA1 mRNA levels in clinical breast cancer specimens. Carcinogenesis 2000, 21:1761-1765.

40. Turner NC, Reis-Filho JS, Russell AM, Springall RJ, Ryder K, Steele D, Savage K, Gillett CE, Schmitt FC, Ashworth A, Tutt AN: BRCA1 dysfunction in sporadic basal-like breast cancer. Oncogene 2007, 26:2126-2132.

41. Morris GJ, Naidu S, Topham AK, Guiles F, Xu Y, McCue P, Schwartz GF, Park PK, Rosenberg AL, Brill K, Mitchell EP: Differences in breast carcinoma characteristics in newly diagnosed African-American and Caucasian patients: a single-institution compilation compared with the National Cancer Institute's Surveillance, Epidemiology, and End Results database. Cancer 2007, 110:876-884.

42. Rakha EA, Reis-Filho JS, Ellis IO: Basal-like breast cancer: a critical review. J Clin Oncol 2008, 26:2568-2581.

43. Schneider BP, Winer EP, Foulkes WD, Garber J, Perou CM, Richardson A, Sledge GW, Carey LA: Triple-negative breast cancer: risk factors to potential targets. Clin Cancer Res 2008, 14:8010-8018.

44. Gluz O, Liedtke C, Gottschalk N, Pusztai L, Nitz U, Harbeck N: Triplenegative breast cancer-current status and future directions. Ann Oncol 2009, 20:1913-1927.

45. Fulford LG, Reis-Filho JS, Ryder K, Jones C, Gillett CE, Hanby A, Easton D, Lakhani SR: Basal-like grade III invasive ductal carcinoma of the breast: patterns of metastasis and long-term survival. Breast Cancer Res 2007, 9:R4.

46. Voduc KD, Cheang MC, Tyldesley S, Gelmon K, Nielsen TO, Kennecke H: Breast cancer subtypes and the risk of local and regional relapse. J Clin Oncol 2010, 28:1684-1691.

47. Kriege M, Seynaeve C, Meijers-Heijboer H, Collee JM, Menke-Pluymers MB, Bartels CC, Tilanus-Linthorst MM, Blom J, Huijskens E, Jager A, et al: Sensitivity to first-line chemotherapy for metastatic breast cancer in BRCA1 and BRCA2 mutation carriers. J Clin Oncol 2009, 27:3764-3771. 
48. Citron ML, Berry DA, Cirrincione C, Hudis C, Winer EP, Gradishar WJ, Davidson NE, Martino S, Livingston R, Ingle JN, et al: Randomized trial of dose-dense versus conventionally scheduled and sequential versus concurrent combination chemotherapy as postoperative adjuvant treatment of node-positive primary breast cancer: first report of Intergroup Trial C9741/Cancer and Leukemia Group B Trial 9741. J Clin Oncol 2003, 21:1431-1439.

49. Hayes DF, Thor AD, Dressler LG, Weaver D, Edgerton S, Cowan D, Broadwater G, Goldstein LJ, Martino S, Ingle JN, et al: HER2 and response to paclitaxel in node-positive breast cancer. N Engl J Med 2007, 357:1496-1506

50. Ellis P, Barrett-Lee $P$, Johnson L, Cameron D, Wardley A, O'Reilly $S$, Verrill M, Smith I, Yarnold J, Coleman R, et al: Sequential docetaxel as adjuvant chemotherapy for early breast cancer (TACT): an open-label, phase III, randomised controlled trial. Lancet 2009, 373:1681-1692.

51. Rouzier R, Perou CM, Symmans WF, Ibrahim N, Cristofanilli M, Anderson K, Hess KR, Stec J, Ayers M, Wagner P, et al: Breast cancer molecular subtypes respond differently to preoperative chemotherapy. Clin Cancer Res 2005, 11:5678-5685.

52. Carey LA, Dees EC, Sawyer L, Gatti L, Moore DT, Collichio F, Ollila DW, Sartor $\mathrm{Cl}$, Graham ML, Perou CM: The triple negative paradox: primary tumor chemosensitivity of breast cancer subtypes. Clin Cancer Res 2007, 13:2329-2334.

53. Liedtke C, Mazouni C, Hess KR, Andre F, Tordai A, Mejia JA, Symmans WF, Gonzalez-Angulo AM, Hennessy B, Green M, et al: Response to neoadjuvant therapy and long-term survival in patients with triplenegative breast cancer. J Clin Oncol 2008, 26:1275-1281.

54. Martin LP, Hamilton TC, Schilder RJ: Platinum resistance: the role of DNA repair pathways. Clin Cancer Res 2008, 14:1291-1295.

55. Kelland L: The resurgence of platinum-based cancer chemotherapy. Nat Rev Cancer 2007, 7:573-584.

56. Kennedy RD, Quinn JE, Mullan PB, Johnston PG, Harkin DP: The role of BRCA1 in the cellular response to chemotherapy. J Natl Cancer Inst 2004, 96:1659-1668.

57. Byrski T, Gronwald J, Huzarski T, Grzybowska E, Budryk M, Stawicka M, Mierzwa T, Szwiec M, Wisniowski R, Siolek M, et al: Pathologic complete response rates in young women with $B R C A 1$-positive breast cancers after neoadjuvant chemotherapy. J Clin Oncol 2010, 28:375-379.

58. Silver DP, Richardson AL, Eklund AC, Wang ZC, Szallasi Z, Li Q, Juul N, Leong CO, Calogrias D, Buraimoh A, et al: Efficacy of neoadjuvant Cisplatin in triple-negative breast cancer. J Clin Oncol 2010, 28:1145-1153.

59. Ryan PD, Tung NM, Isakoff SJ, Golshan M, Richardson A, Corben AD, Smith BL, Gelman R, Winer EP, Garber JE: Neoadjuvant cisplatin and bevacizumab in triple negative breast cancer (TNBC): Safety and efficacy [abstract 551]. J Clin Oncol 2009, 27:551.

60. Torrisi R, Balduzzi A, Ghisini R, Rocca A, Bottiglieri L, Giovanardi F, Veronesi P, Luini A, Orlando L, Viale G, et al: Tailored preoperative treatment of locally advanced triple negative (hormone receptor negative and HER2 negative) breast cancer with epirubicin, cisplatin, and infusional fluorouracil followed by weekly paclitaxel. Cancer Chemother Pharmacol 2008, 62:667-672.

61. Frasci G, Comella P, Rinaldo M, lodice G, Di Bonito M, D'Aiuto M, Petrillo A, Lastoria S, Siani C, Comella G, D'Aiuto G: Preoperative weekly cisplatinepirubicin-paclitaxel with G-CSF support in triple-negative large operable breast cancer. Ann Oncol 2009, 20:1185-1192.

62. Isakoff SJ: Triple-negative breast cancer: role of specific chemotherapy agents. Cancer J 2010, 16:53-61.

63. Leong CO, Vidnovic N, DeYoung MP, Sgroi D, Ellisen LW: The p63/p73 network mediates chemosensitivity to cisplatin in a biologically defined subset of primary breast cancers. J Clin Invest 2007, 117:1370-1380.

64. Kavallaris M: Microtubules and resistance to tubulin-binding agents. Nat Rev Cancer 2010, 10:194-204.

65. Rugo HS, Thomas ES, Lee RK, Fein LE, Peck R, Verrill M: Combination therapy with the novel epothilone $B$ analog, ixabepilone, plus capecitabine has efficacy in ER/PR/HER2-negative breast cancer resistant to anthracyclines and taxanes. Breast Cancer Res Treat 2007, 106: S270-S270.

66. Baselga J, Zambetti M, Llombart-Cussac A, Manikhas G, Kubista E, Steger GG, Makhson A, Tjulandin S, Ludwig H, Verrill M, et al: Phase II genomics study of ixabepilone as neoadjuvant treatment for breast cancer. J Clin Oncol 2009, 27:526-534.
67. Horak CE, Lee FY, Xu L, Galbraith S, Baselga J: High \{beta\}-III tubulin expression in triple-negative (TN) breast cancer (BC) subtype and correlation to ixabepilone response: A retrospective analysis[abstract 3587]. J Clin Oncol 2009, 27:3587.

68. Twelves C, Loesch D, Blum JL, Vahdat LT, Petrakova K, Chollet PJ, Akerele CE, Seegobin S, Wanders J, Cortes J: A phase III study (EMBRACE) of eribulin mesylate versus treatment of physician's choice in patients with locally recurrent or metastatic breast cancer previously treated with an anthracycline and a taxane. [abstract 1004]. J Clin Oncol 2010, 28.

69. Ashworth A: A synthetic lethal therapeutic approach: poly(ADP) ribose polymerase inhibitors for the treatment of cancers deficient in DNA double-strand break repair. J Clin Oncol 2008, 26:3785-3790.

70. Rouleau M, Patel A, Hendzel MJ, Kaufmann SH, Poirier GG: PARP inhibition: PARP1 and beyond. Nat Rev Cancer 2010, 10:293-301.

71. Kraus WL: Transcriptional control by PARP-1: chromatin modulation, enhancer-binding, coregulation, and insulation. Curr Opin Cell Biol 2008, 20:294-302.

72. Curtin NJ: PARP inhibitors for cancer therapy. Expert Rev Mol Med 2005 7:1-20.

73. Iglehart JD, Silver DP: Synthetic lethality-a new direction in cancer-drug development. N Engl J Med 2009, 361:189-191.

74. Farmer H, McCabe N, Lord CJ, Tutt AN, Johnson DA, Richardson TB, Santarosa M, Dillon KJ, Hickson I, Knights C, et al: Targeting the DNA repair defect in BRCA mutant cells as a therapeutic strategy. Nature 2005, 434:917-921.

75. McCabe N, Turner NC, Lord CJ, Kluzek K, Bialkowska A, Swift S, Giavara S, O'Connor MJ, Tutt AN, Zdzienicka MZ, et al: Deficiency in the repair of DNA damage by homologous recombination and sensitivity to poly (ADP-ribose) polymerase inhibition. Cancer Res 2006, 66:8109-8115.

76. Tutt A, Robson M, Garber JE, Domchek SM, Audeh MW, Weitzel JN, Friedlander M, Arun B, Loman N, Schmutzler RK, et al: Oral poly(ADPribose) polymerase inhibitor olaparib in patients with BRCA1 or BRCA2 mutations and advanced breast cancer: a proof-of-concept trial. Lancet 2010, 376:235-244

77. Dent R, Lindeman G, Clemons M, Wildiers H, Chan A, McCarthy N, Singer C, Lowe E, Kemsley K, Carmichael J: Safety and efficacy of the oral PARP inhibitor olaparib (AZD2281) in combination with paclitaxel for the firstor second-line treatment of patients with metastatic triple-negative breast cancer: Results from the safety cohort of a phase $1 / 1$ multicenter trial. [abstract 1018]. J Clin Oncol 2010, 28:118s.

78. O'Shaughnessy J, Osborne C, Pippen J, Patt D, Rocha C, Ossovskaya V, Sherman B, Bradley C: Final Results of a Randomized Phase II Study Demonstrating Efficacy and Safety of BSI-201, a Poly (ADP-Ribose) Polymerase (PARP) Inhibitor, in Combination with Gemcitabine/ Carboplatin (G/C) in Metastatic Triple Negative Breast Cancer (TNBC). Cancer Res 2009, 69:686S-687S.

79. O'Shaughnessy J, Osborne C, Pippen J, Yoffe M, Patt D, Monaghan G, Rocha C, Ossovskaya V, Sherman B, Bradley C: Efficacy of BSI-201, a poly (ADP-ribose) polymerase-1 (PARP1) inhibitor, in combination with gemcitabine/carboplatin $(\mathrm{G} / \mathrm{C})$ in patients with metastatic triple-negative breast cancer (TNBC): Results of a randomized phase II trial. J Clin Oncol 2009, 27:3-3.

80. von Minckwitz G, Müller B, Loibl S, Blohmer JU, du Bois A, Huober J, Kandolf R, Budczies J, Denkert C: PARP is expressed in all subtypes of early breast cancer and is a predictive factor for response to neoadjuvant chemotherapy. European Journal of Cancer Supplements 2010, 8.

81. Isakoff SJ, Overmoyer B, Tung NM, Gelman RS, Giranda VL, Bernhard KM, Habin KR, Winer EP, Goss PE: A phase II trial of the PARP inhibitor veliparib (ABT888) and temozolomide for metastatic breast cancer. J Clin Oncol (Meeting Abstracts) 2010, 28:1019.

82. Loibl S, Mueller B, von Minckwitz G, Blohmer JU, du Bois A, Huober J, Fend F, Budczies J, Denkert C: PARP expression in early breast cancer and its predictive value for response to neoadjuvant chemotherapy[abstract 10511. J Clin Oncol 2010, 28.

83. Pandolfi PP: Breast cancer-loss of PTEN predicts resistance to treatment. N Engl J Med 2004, 351:2337-2338.

84. Saal LH, Johansson P, Holm K, Gruvberger-Saal SK, She QB, Maurer M, Koujak S, Ferrando AA, Malmstrom P, Memeo L, et al: Poor prognosis in carcinoma is associated with a gene expression signature of aberrant 
PTEN tumor suppressor pathway activity. Proc Natl Acad Sci USA 2007, 104:7564-7569.

85. Kwei KA, Kung Y, Salari K, Holcomb IN, Pollack JR: Genomic instability in breast cancer: Pathogenesis and clinical implications. Mol Oncol 2010.

86. Carey LA, Rugo HS, Marcom PK, Irvin W Jr, Ferraro M, Burrows E, He X, Perou CM, Winer EP, on behalf of the Translational Breast Cancer Research C: TBCRC 001: EGFR inhibition with cetuximab added to carboplatin in metastatic triple-negative (basal-like) breast cancer[abstract 1009]. J Clin Oncol 2008, 26:1009.

87. O'Shaughnessy J, Weckstein DJ, Vukelja SJ, McIntyre K, Krekow L, Holmes FA, Asmar L, Blum JL: Preliminary results of a randomized phase II study of weekly irinotecan/carboplatin with or without cetuximab in patients with metastatic breast cancer. Breast Cancer Res Treat 2007, 106:S32-S33.

88. Carey LA, O'Shaughnessy JA, Hoadley K, Khambata-Ford S, Horak CE, Xu LA, Awad M, Brickman D, Muller S, Donato J, et al: Potential Predictive Markers of Benefit from Cetuximab in Metastatic Breast Cancer: An Analysis of Two Randomized Phase 2 Trials. Cancer Res 2009, 69:5965-5965.

89. Weiner LM: Building better magic bullets-improving unconjugated monoclonal antibody therapy for cancer. Nat Rev Cancer 2007, 7:701-706.

90. Yeatman TJ: A renaissance for SRC. Nat Rev Cancer 2004, 4:470-480.

91. Bromann PA, Korkaya H, Courtneidge SA: The interplay between Src family kinases and receptor tyrosine kinases. Oncogene 2004, 23:7957-7968

92. Ottenhoff-Kalff AE, Rijksen G, van Beurden EA, Hennipman A, Michels AA, Staal GE: Characterization of protein tyrosine kinases from human breast cancer: involvement of the c-src oncogene product. Cancer Res 1992, 52:4773-4778.

93. Xu J, Wu RC, O'Malley BW: Normal and cancer-related functions of the p160 steroid receptor co-activator (SRC) family. Nat Rev Cancer 2009, 9:615-630.

94. Huang F, Reeves K, Han X, Fairchild C, Platero S, Wong TW, Lee F, Shaw P, Clark E: Identification of candidate molecular markers predicting sensitivity in solid tumors to dasatinib: rationale for patient selection. Cancer Res 2007, 67:2226-2238.

95. Finn RS, Dering J, Ginther C, Wilson CA, Glaspy P, Tchekmedyian N, Slamon DJ: Dasatinib, an orally active small molecule inhibitor of both the src and abl kinases, selectively inhibits growth of basal-type/"triplenegative" breast cancer cell lines growing in vitro. Breast Cancer Res Treat 2007, 105:319-326.

96. Finn RS, Bengala C, Ibrahim N, Strauss LC, Fairchild J, Sy O, Roche H, Sparano J, Goldstein L: Phase II trial of dasatinib in triple-negative breast cancer: results of study CA 180059. Cancer Res 2009, 69:237S-237S.

97. Moulder S, Yan K, Huang F, Hess KR, Liedtke C, Lin F, Hatzis C, Hortobagyi GN, Symmans WF, Pusztai L: Development of candidate genomic markers to select breast cancer patients for dasatinib therapy. Mol Cancer Ther 2010, 9:1120-1127.

98. Linderholm BK, Hellborg H, Johansson U, Elmberger G, Skoog L, Lehtio J, Lewensohn R: Significantly higher levels of vascular endothelial growth factor (VEGF) and shorter survival times for patients with primary operable triple-negative breast cancer. Ann Oncol 2009, 20:1639-1646.

99. Miller K, Wang M, Gralow J, Dickler M, Cobleigh M, Perez EA, Shenkier T, Cella D, Davidson NE: Paclitaxel plus bevacizumab versus paclitaxel alone for metastatic breast cancer. N Engl J Med 2007, 357:2666-2676.

100. O'Shaughnessy J, Dieras V, Glaspy J, Brufsky A, Miller K, Miles D, Koralewski P, Phan S, Bhattacharya S: Comparison of Subgroup Analyses of PFS from Three Phase III Studies of Bevacizumab in Combination with Chemotherapy in Patients with HER2-Negative Metastatic Breast Cancer (MBC). Cancer Res 2009, 69:207.

101. Chan A, Miles DW, Pivot X: Bevacizumab in combination with taxanes for the first-line treatment of metastatic breast cancer. Ann Oncol 2010.

102. Robert NJ, Dieras V, Glaspy J, Brufsky A, Bondarenko I, Lipatov O, Perez E, Yardley D, Zhou X, Phan S: RIBBON-1: Randomized, double-blind, placebo-controlled, phase III trial of chemotherapy with or without bevacizumab (B) for first-line treatment of HER2-negative locally recurrent or metastatic breast cancer (MBC)[abstract 1005]. J Clin Oncol 2009, 27:1005.

103. O'Shaughnessy J, Miles D, Gray RJ, Dieras V, Perez E, Zon J, Cortes J, Zhou X, Phan S, Miller K: A meta-analysis of overall survival data from three randomized trials of bevacizumab (BV) and first-line chemotherapy as treatment for patients with metastatic breast cancer (MBC)[abstract 1005]. J Clin Oncol 2010, 7S.
104. Burstein HJ, Elias AD, Rugo HS, Cobleigh MA, Wolff AC, Eisenberg PD, Lehman M, Adams BJ, Bello CL, DePrimo SE, et al: Phase II study of sunitinib malate, an oral multitargeted tyrosine kinase inhibitor, in patients with metastatic breast cancer previously treated with an anthracycline and a taxane. J Clin Oncol 2008, 26:1810-1816.

105. Berg J, Greil R, Voytjo N, Makhson A, Cortes J, Lortholary A, Huang X, Giorgetti C, Kern KA, Lichinister M: Sunitinib (SU) in combination with docetaxel (D) versus $D$ alone for the first-line treatment of advanced breast cancer (ABC)[abstract 1010]. J Clin Oncol 2010, 28.

106. Crown J, Dieras V, Starolawska DA, Yardley D, Davidson NE, Bachelot VR, Tassell VR, Huang X, Kern KA, Romieu G: Phase III trial of sunitinib (SU) in combination with capecitabine (C) versus $C$ in previously treated advanced breast cancer (ABC)[abstract 1011 ]. J Clin Oncol 2010, 28

107. Meric-Bernstam F, Gonzalez-Angulo AM: Targeting the mTOR signaling network for cancer therapy. J Clin Oncol 2009, 27:2278-2287.

108. Ellard SL, Clemons M, Gelmon KA, Norris B, Kennecke H, Chia S, Pritchard K, Eisen A, Vandenberg T, Taylor M, et al: Randomized phase II study comparing two schedules of everolimus in patients with recurrent/ metastatic breast cancer: NCIC Clinical Trials Group IND.163. I Clin Oncol 2009, 27:4536-4541.

109. Doane AS, Danso M, Lal P, Donaton M, Zhang L, Hudis C, Gerald WL: An estrogen receptor-negative breast cancer subset characterized by a hormonally regulated transcriptional program and response to androgen. Oncogene 2006, 25:3994-4008.

110. Gonzalez-Angulo AM, Stemke-Hale K, Palla SL, Carey M, Agarwal R, MericBerstam F, Traina TA, Hudis C, Hortobagyi GN, Gerald WL, et al: Androgen receptor levels and association with PIK3CA mutations and prognosis in breast cancer. Clin Cancer Res 2009, 15:2472-2478.

111. Niemeier LA, Dabbs DJ, Beriwal S, Striebel JM, Bhargava R: Androgen receptor in breast cancer: Expression in estrogen receptor-positive tumors and in estrogen receptor-negative tumors with apocrine differentiation. Modern Pathology 2010, 23:205-212.

112. Park S, Koo J, Park HS, Kim JH, Choi SY, Lee JH, Park BW, Lee KS: Expression of androgen receptors in primary breast cancer. Annals of Oncology 2009, 21:488-492.

113. Di Cosimo S, Baselga J: Management of breast cancer with targeted agents: importance of heterogenicity. Nat Rev Clin Oncol 2010, 7:139-147.

114. Turner $\mathrm{N}$, Grose R: Fibroblast growth factor signalling: from development to cancer. Nat Rev Cancer 2010, 10:116-129.

115. Elbauomy Elsheikh S, Green AR, Lambros MB, Turner NC, Grainge MJ, Powe D, Ellis IO, Reis-Filho JS: FGFR1 amplification in breast carcinomas: a chromogenic in situ hybridisation analysis. Breast Cancer Res 2007, 9:R23.

116. Hunter DJ, Kraft P, Jacobs KB, Cox DG, Yeager M, Hankinson SE, Wacholder S, Wang Z, Welch R, Hutchinson A, et al: A genome-wide association study identifies alleles in FGFR2 associated with risk of sporadic postmenopausal breast cancer. Nat Genet 2007, 39:870-874.

117. Sebolt-Leopold JS, Herrera R: Targeting the mitogen-activated protein kinase cascade to treat cancer. Nat Rev Cancer 2004, 4:937-947.

118. Saal LH, Gruvberger-Saal SK, Persson C, Lovgren K, Jumppanen M, Staaf J, Jonsson G, Pires MM, Maurer M, Holm K, et al: Recurrent gross mutations of the PTEN tumor suppressor gene in breast cancers with deficient DSB repair. Nat Genet 2008, 40:102-107.

119. Mirzoeva OK, Das D, Heiser LM, Bhattacharya S, Siwak D, Gendelman R, Bayani N, Wang NJ, Neve RM, Guan Y, et al: Basal subtype and MAPK/ERK kinase (MEK)-phosphoinositide 3-kinase feedback signaling determine susceptibility of breast cancer cells to MEK inhibition. Cancer Res 2009, 69:565-572.

120. Hoeflich KP, O'Brien C, Boyd Z, Cavet G, Guerrero S, Jung K, Januario T, Savage $H$, Punnoose E, Truong T, et al: In vivo antitumor activity of MEK and phosphatidylinositol 3-kinase inhibitors in basal-like breast cancer models. Clin Cancer Res 2009, 15:4649-4664.

121. Speers C, Tsimelzon A, Sexton K, Herrick AM, Gutierrez C, Culhane A, Quackenbush J, Hilsenbeck S, Chang J, Brown P: Identification of novel kinase targets for the treatment of estrogen receptor-negative breast cancer. Clin Cancer Res 2009, 15:6327-6340.

doi:10.1186/1756-8722-3-42

Cite this article as: Santana-Davila and Perez: Treatment options for patients with triple-negative breast cancer. Journal of Hematology \& Oncology 2010 3:42 